\title{
Isolasi Bakteri Asam Laktat (BAL) Penghasil Asam Glutamat dari Ikan Budu sebagai Feed Suplemen Ayam Broiler
}

\section{Isolation of Lactic Acid Bacteria (LAB) for Glutamate Acid-Producing from Budu Fish as Feed Supplement of Broiler Chicken}

\author{
V. Maslami ${ }^{1 *}$, Y. Marlida ${ }^{2}$, Mirnawati ${ }^{2}$, Jamsari $^{3}$, dan Y. S. Nur ${ }^{2}$ \\ ${ }^{1}$ Program Pascasarjana Universitas Andalas \\ ${ }^{2}$ Fakultas Peternakan Universitas Andalas \\ ${ }^{3}$ Fakultas Pertanian Universitas Andalas \\ Kampus Unand Limau Manis, Padang, Indonesia, 25163 \\ *E-mail: veramaslami@gmail.com \\ (Diterima: 16 Oktober 2017; Disetujui: 5 Desember 2017)
}

\begin{abstract}
ABSTRAK
Asam glutamat merupakan asam amino building blocks asam amino lainnya dan neurotransmitter pembentuk citra rasa. Bakteri Asam Laktat (BAL) adalah salah satu mikrooganisme penghasil asam glutamat yang banyak terdapat pada produk fermentasi. Ikan budu merupakan fermentasi ikan Tenggiri (Scomberomorus guttatus) dan Talang-Talang (Chorinemus lyson L) yang diproduksi di daerah pesisir Kabupaten Padang Pariaman. Pada penelitian ini dilakukan tiga tahap. Tahap 1: isolasi BAL yang berasal dari fermentasi ikan budu. Tahap 2: seleksi kualitatif dan kuantitatif BAL penghasil asam glutamat. Tahap 3: karakterisasi BAL penghasil asam glutamat. Hasil yang diperoleh terdapat 17 isolat BAL yang kemudian diseleksi secara kualitatif menggunakan thin layer chromatographic yang direndam dalam campuran pelarut n-butanol, asam asetat dan air (4:1:1 v/v) terdapat 16 yang dapat menghasilkan asam glutamat. Setelah dilakukan seleksi kualitatif selanjutnya dilakukan seleksi kuantitatif dengan spectrophotometer panjang gelombang $570 \mathrm{~nm}$. Produksi asam glutamat yang tertinggi terdapat pada isolate IB.9 dengan produksi $13.03 \mathrm{mg} / \mathrm{ml}$. Isolate dan IB.9 yang paling tinggi dalam menghasilkan asam glutamat dikarakteristik yang berpedoman Bergey's manual of systemic bacteriology merupakan genus Lactobacillus sp. Penelitian ini dapat disimpulkan terdapat isolat BAL IB.9 (Lactobacillus $s p$ ) yang berpotensi dalam menghasilkan asam glutamat dengan produksi $13.03 \mathrm{mg} / \mathrm{ml}$.
\end{abstract}

Kata kunci: asam glutamat, ayam broiler, BAL, ikan Budu, fermentasi

\begin{abstract}
Glutamate acid is the amino acid building blocks of other amino acids and neurotransmitters forming the image of taste. Lactic Acid Bacteria (LAB) is one of the glutamate acid-producing microorganisms are widely found in fermented products. Budu fish is fermented mackerel (Scomberomorus guttatus) and Talang-Talang (Chorinemus Lyson L) produced in coastal areas Padang Pariaman. The study consisted of three stages. Stage 1: LAB isolation from fermented Ikan Budu. Stage 2: Qualitative and quantitative selection of $L A B$ which producing glutamate acid. Stage 3: Characterization the best LAB in producing acid glutamate. The results are obtained 17 isolates of $L A B$ were then selected qualitatively using TLC (thin layer chromatographic) were immersed in a solvent mixture of n-butanol, acetic acid and water (4:1:1 $v / v)$ that 16 isolates of LAB producing glutamate acid. After the selection is the performed qualitative and quantitative selection with spectrophotometer was measured at $570 \mathrm{~nm}$. Highest Glutamate acid production is isolated IB.9 $13.03 \mathrm{mg} / \mathrm{ml}$. The characterization of two isolates and IB.9 highest in producing glutamate acid reference to Bergey's manual of systemic bacteriology as the genus Lactobacillus sp. Based on the characterization, the 2 isolates were Lactobacillus sp. The conclusion from this study is there isolates IB.9 (Lactobacillus sp) which potential to produce glutamate acid with the production of $13.03 \mathrm{mg} / \mathrm{ml}$.
\end{abstract}

Keywords: budu fish, broiler chicken, fermentation, glutamic acid, LAB 


\section{PENDAHULUAN}

Ayam broiler merupakan salah satu ternak penghasil daging yang cukup potensial dalam memenuhi kebutuhan masyarakat akan protein hewani. Hal ini disebabkan daging ayam broiler relatif murah dan mudah didapatkan dibandingkan protein hewani lainnya. Dilihat dari perkembangannya ternak ayam broiler di Indonesia terus meningkat tiap tahunnya. Menurut Dirjen Peternakan (2015) populasi ayam broiler di Indonesia pada tahun 2015 mencapai 1.498 juta ekor, meningkat sekitar $27,13 \%$ dari populasi lima tahun sebelumnya 1.178 juta ekor. Tingginya populasi ternak ayam harus ditunjang dengan kualitas karkas ayam broiler yang baik, karena masyarakat sudah sangat memperhatikan tentang kualitas daging yang dipilihnya. Masyarakat tentu akan memilih daging yang mempunyai kualitas baik sesuai dengan biaya yang dikeluarkan.

Menurut Kasih (2012) karkas ayam broiler mempunyai tekstur daging yang lunak dengan kandungan lemak yang lebih tinggi dibanding dengan ayam buras. Tesktur daging yang lunak pada ayam broiler menyebabkan memar merah pada karkas yang dijual dipasaran, sehingga mempengaruhi permintaan konsumen. Selain itu, karkas ayam broiler mengalami penurunan cita rasa akibat adanya rekayasa genetika (Fujimura et al., 2001). Penurunan kualitas karkas ayam broiler menyebabkan banyak konsumen yang beralih pada ayam buras. Hal ini dikarenakan daging ayam kampung memiliki aroma yang spesifik dan rasanya yang lebih gurih dibandingkan dengan produk olahan ayam broiler (Aman, 2011).

Untuk meningkatkan kualitas karkas ayam broiler perlu dilakukan perbaikan kandungan gizi pakan. Salah satunya dengan menambahkan asam glutamat pada pakan ayam broiler. Asam glutamat merupakan asam amino non esensial, yang berfungsi sebagai Building Blocks asam amino, substrat dalam sintesis protein, sebagai prekursor glutamin (Gln) dan sebagai neurotransmiter
(Young and Ajami 2000; Pierre-Andre and Yves, 2004). Selanjutnya, menurut Fujimura et al. (2001) fungsi lain dari asam glutamat adalah neostransmit untuk cita rasa dimana asam glutamat sebagai satu dari lima selera dasar: umami, yang mencakup selera lezat, umami dan gurih (Lawrie and Ledward, 2006). Ditambahkan Kato dan Nishimura (1987); Fujimura et al. (1996) komponen utama rasa dalam daging, dan merupakan salah satu asam amino terpenting yang meningkatkan rasa daging.

Pemberian asam glutamat pada ayam broiler telah dilakukan oleh beberapa peneliti. Menurut Berres et al. (2010); Ajinamoto (2007) pemberian asam glutamat pada ayam broiler menurunkan lemak abdomen, memperbaiki testur daging dengan mengurangi memar merah pada karkas dan meningkatkan kandungan protein daging. Ditambahkan Fujimura et al. (2001) pemberian $0.75 \%$ asam glutamat dari kebutuhan dalam ransum meningkatkan asam glutamat bebas dalam otot, dan meningkatkan rasa umami daging yang diberikan asam glutamat secara ad libitum (Imanari et al., 2004). Penambahan asam glutamat pada ransum ayam broiler selain memperbaiki kualitas karkas juga dapat meningkatkan laju pembentukan jaringan ikat selama periode pertumbuhan, sehingga meningkatkan bobot badan ayam broiler (Zhang et al., 2008).

Sejumlah penelitian tentang produksi asam glutamat dari mikroorganisme telah banyak dilakukan. BAL merupakan salah satu bakteri gram positif yang menghasilkan asam glutamat dinilai ramah lingkungan yang dikenal dengan baik penghasil berbagai metabolit primer. Keberadaan gen $G D H$ yang bertanggung jawab untuk memproduksi asam glutamat yang menjadi kelebihan BAL dari mikroba lainnya (Sano, 2009). BAL yang dapat menghasilkan asam glutamat diantaranya; Lactobacillus plantarum MNZ ( Zerean et al., 2012), Bacillus (Lawal et al., 2011), Lactobacillus (Zalan et al., 2010), Lactobacillus strains (Terek and Mostafa, 2010). Mencari sumber-sumber mikro- 
organisme BAL produktif menghasilkan asam glutamat adalah langkah yang paling memungkinkan untuk dilakukan.

Sumatera Barat memiliki banyak sumber-sumber pangan fermentasi salah satunya adalah ikan Budu. Ikan Budu merupakan produk fermentasi ikan tenggiri (Scomberomorus guttatus) dan Talang-Talang (Chorinemus lyson $L$ ) yang diproduksi di daerah pesisir Kabupaten Padang Pariaman, Agam dan Pasaman (Yusra et al., 2014). Pada produk fementasi ikan Budu ini ditemukan bakteri genus Bacillus dan Micrococcus (Bacillus sphaericus, Bacillus polymyxa, Bacillus cereus, Bacillus pantothenticus dan Micrococcus lactis) (Yusra et al., 2014). Selanjutnya, keanekaragaman jenis BAL tersebut perlu dieksplorasi sifat-sifat dan potensinya sebagai penghasil asam glutamat.

\section{METODE}

\section{Isolasi Bakteri Asam Laktat (BAL) dari Ikan Budu}

Isolasi BAL dari pangan fermentasi menggunakan metode Adnan dan Tan (2007). Sampel di homogenizer dalam $0,85 \% \mathrm{NaCl}$ dan dinkubasi pada suhu $30^{\circ} \mathrm{C}$ selama 24 jam dalam kondisi an-aerob. Untuk membedakan BAL dengan bakteri lainnya, $2 \% \mathrm{CaCO}_{3}$ ditambahkan pada MRS agar yang mengandung $10 \% \mathrm{NaCl}$. Koloni yang terbentuk dengan adanya zona bening BAL. Skrining BAL penghasil asam glutamate

\section{Skrining BAL Penghasil Asam Glutamat}

Semua isolat BAL dilakukan seleksi kualitatif dan kuantitatif dalam menghasilkan asam glutamat. Seleksi dimulai dengan cara menambahkan $6 \%$ glukosa dan $30 \mu \mathrm{g}$ biotin pada MRS cair dan dinkubasi selama 72 jam pada suhu $30^{\circ} \mathrm{C}$ dalam kondisi an aerob (Zareian et al., 2012). Medium fermentasi disentrifugasi pada $10.000 \mathrm{rpm}$ selama 20 menit. Seleksi kualitatif dengan menggunakan thin layernchromatography plates (TLC). Supernatan yang telah di setrifugase diteteskan pada TLC dan rendam dalam campuran pelarut n-butanol, asam asetat dan air $(4: 1: 1 \mathrm{v} / \mathrm{v})$ untuk fase gerak. TLC dikeringkan, lalu semprot dengan $0,2 \%$ $(\mathrm{w} / \mathrm{v})$ ninhidrin, kemudian dipanaskan pada suhu $110^{\circ} \mathrm{C}$ selama 3 menit. Bintik dan warna nilai RF dibandingkan dengan standar asam glutamat (Ogbadu et al., 1990).

Penentuan asam glutamat secara kuantitatif menggunakan metode Spies (1957) yang dimodifikasi Lawal et al. (2011). Menggunakan reaksi warna ninhidrin dan absorbansi yang diukur pada $570 \mathrm{~nm}$. Sampel setiap aliquot dari media fermentasi, diambil $1 \mathrm{ml}$ dan ditambahkan ke $1 \mathrm{ml}$ reagen ninhidrin 0,1 $\%$ yang dilarutkan dalam etanol. Campuran dipanaskan dalam water bath selama 5 menit, kemudian didinginkan pada suhu ruang. Absorbansi larutan yang telah berubah warna dibaca menggunakan spektrofotometer 570 $\mathrm{nm}$. Kandungan asam glutamat dalam sampel ditentukan dengan mengacu pada kurva standar konsentrasi asam glutamat.

\section{Identifikasi BAL terpilih penghasil asam glutamat}

Isolat yang di isolasi sebagai $\mathrm{BAL}$ dikarakterisasi secara biokimia sesuai prosedur Collins dan Lyne (1976) dan Gordon et al. (1973). Tes yang digunakan adalah; pewarnaan Gram, katalase, oksidase, mortilitas, laktosa, glukosa, mannitol, VP, OF, arginine, aesculin, arabinose, raffinose, sorbitol, trehalase, maltose, melezitos dan nitrat. Hasil yang diperoleh dicocokkan pada petunjuk Bergey Bakteriologi Sistemik (Sneath et al., 1986).

\section{HASIL DAN PEMBAHASAN}

\section{Isolasi dan Seleksi BAL penghasil Asan Glutamat dari Ikan Budu}

Pada penelitian ini menggunakan fermentasi ikan budu yang diambil dari daerah Padang Pariaman Provinsi Sumatera Barat. Isolasi BAL dilakukan pada media MRS broth di inkubasi selama 7 hari. Hasil penelitian menunjukkan terdapat 17 isolat BAL yang dilihat dari zona bening di 


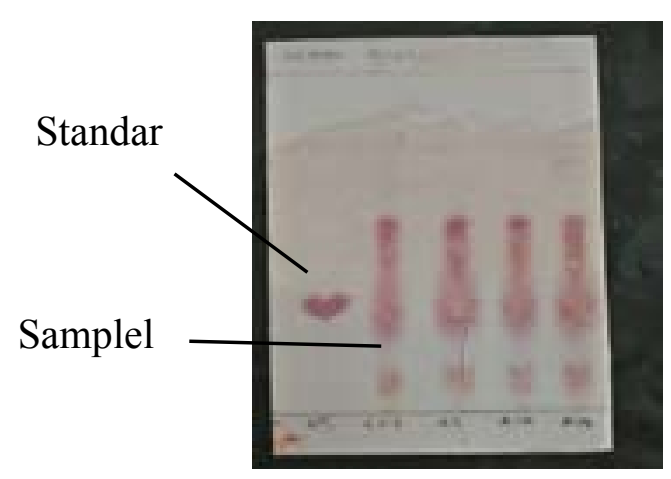

A

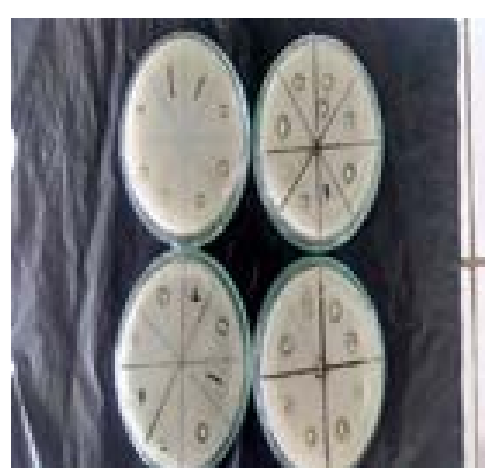

B

Gambar 1. A. Seleksi TLC; B. Zona bening

Tabel 1. Seleksi kualitatif dan kuantitatif BAL Penghasil Asam Glutamat.

\begin{tabular}{ccc}
\hline \multirow{2}{*}{ Isolat } & \multicolumn{2}{c}{ Seleksi BAL Penghasil Asam Glutamat } \\
\cline { 2 - 3 } & Kualitatif & Kuantitatif $(\mathrm{mg} / \mathrm{ml})$ \\
\hline IB.1 & + & 8.86 \\
IB.2 & + & 8.75 \\
IB.3 & + & 8.69 \\
IB.4 & + & 8.75 \\
IB.5 & + & 8.36 \\
IB.6 & + & 7.53 \\
IB.7 & + & 12.36 \\
IB.8 & + & 3.53 \\
IB.9 & + & 13.03 \\
IB.10 & + & 3.19 \\
IB.11 & + & 8.36 \\
IB.12 & + & 7.19 \\
IB.13 & - & - \\
IB.14 & + & 3.25 \\
IB.15 & + & 9.36 \\
IB.16 & + & 6.81 \\
IB.17 & + & 7.31 \\
\hline
\end{tabular}

sekitar media MRS agar yang ditambahkan $2 \% \mathrm{CaCO}_{3}$. Isolasi BAL berdasarkan zona bening dapat dilihat pada Gambar 1. Setelah dilakukan selaksi BAL kemudian dilakukan seleksi BAL penghasil asal glutamat dengan menggunakan MRS Broth yang ditambah 0.3 $\mu \mathrm{g}$ biotin dan $12 \%$ glukosa sebagai induser yang diinkubasi selama 72 jam. Penelitian ini didapatkan 17 isolat BAL berdasarkan zona bening asam glutamat dapat dilihat pada Gambar 1. Isolat BAL yang terisolasi diseleksi untuk menghasilkan asam glutamat secara kualitatif dengan menggunakan TLC dan kuantitatif dengan spectrophotometer panjang gelombang $570 \mathrm{~nm}$ didapatkan
16 isolat yang dapat menghasilkan asam glutamat. Isolat BAL penghasil asam glutamat seleksi secara kualitatif dan kuantitatif dari ikan budu disajikan pada Tabel 1 .

Produksi asam glutamat tertinggi terdapat pada isolat BAL isolat IB.9 dengan produksi $13.03 \mathrm{mg} / \mathrm{ml}$. Hal ini menunjukkan bahwa isolat IB.9 berpotensi dalam menghasilkan asam glutamat dibandingkan dengan isolat lainnya. Perbedaan produksi asam glutamat tiap isolat disebabkan kerena perbedaan kemampuan setiap starain BAL. Menurut Kiboem et al. (2001) setiap isolat Lactobacilus mempunyai kemampuan

Isolasi Bakteri Asam Laktat ... (Maslami et al.) 


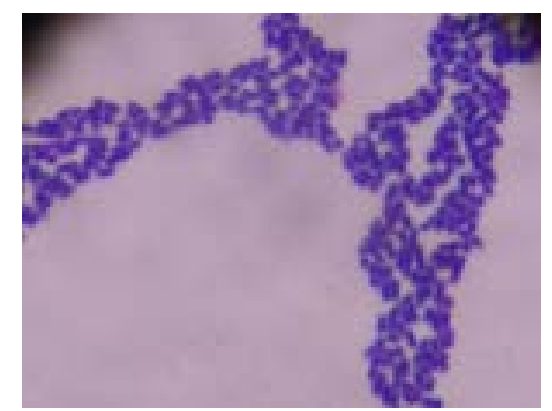

Gambar 2. Morphologi Isolat BAL IB.9 ikan Budu perbesaran 1000 x.

Tabel 2. Karakteristik Isolat BAL asal Ikan Budu.

\begin{tabular}{clc}
\hline \multirow{2}{*}{ No } & Perlakuan & Koloni Yang Diproses \\
\hline 1 & Caloni (warna, bentuk) & IB.9 \\
2 & Gram & Putih, Bacil \\
3 & Aerob/anaerob & Aerob \\
4 & TSIA & Kuning \\
5 & Gas & - \\
6 & Catalase & - \\
7 & Oksidase & - \\
8 & Mortalits & - \\
9 & Laktosa & + \\
10 & Glukosa & + \\
11 & Mannitol & + \\
12 & MR & - \\
13 & VP & - \\
14 & OF & - \\
15 & KCN & - \\
16 & Arginin & + \\
17 & Aeaculin & + \\
18 & Arabinose & - \\
19 & Raffinose & + \\
20 & Sorbitol & + \\
21 & Trehalase & + \\
22 & Maltose & + \\
23 & Melezitose & + \\
24 & Nitrat & + \\
\hline Keterangan & Lactobacillus Sp
\end{tabular}

berbeda dalam memanfaatkan nutrisi pada media sehingga menghasilkan asam amino berbeda termasuk asam glutamat. Produksi asam glutamat yang dihasilkan oleh isolat IB.9 ini lebih tinggi dibandingkan produksi asam glutamat yang dilaporkan oleh Lawal et al. (2011) produksi asam glutamat dari Bacillus spp. $8.3 \mathrm{mg} / \mathrm{ml}$, Zareian et al. (2012) dengan produksi $489 \mu \mathrm{mol} / \mathrm{L}$ dari Lactobacillus plantarum dan Tarek and Mustafa (2010) dengan produksi asam glutamat $68,7 \mathrm{mg} / \mathrm{L}$.

\section{Karakteristik BAL}

Karakteristik BAL penghasil asam glutamat dilakukan pada isolat tertinggi dalam menghasilkan asam glutamat. Tabel 2 terlihat bahwa isolat IB.9 yang ditemukan merupakan Lactobacillus sp. Setiap isolat mempunyai kemampuan berbeda dalam 
menyerap sumber karbon dan menghasilkan asam. Sumber karbon yang digunakan adalah: laktosa, glukosa, mannitol, VP, OF, arginin, aesculin, arabinose, raffinose, sorbitol, trehalase, maltose, melexitose dan nitrat. Kemampuan isolat dalam menyerap karbohidrat merujuk pada karakteristik dan metabolism Lactobacillus yang berpedoman pada Bergey's manual of systemic bacteriology (Sneath et al., 1986).

Pewarnaan gram pada isolat IB.9 berwarna ungu yang menunjukkan bahwa isolat bersifat gram positif (Gambar 2). Hal ini sesuai dengan pendapat Ray (2001) yang menyatakan bahwa prinsip pewarnaan gram yaitu kemampuan dinding sel mengikat zat warna dasar (kristal violet) setelah pencucian dengan alkohol 95\%. Keadaan ini berhubungan dengan komposisi senyawa penyusun dinding sel. Pada bakteri gram positif mengandung peptidoglikan lebih banyak dan lemak lebih sedikit dibandingkan bakteri gram negatif. Hal ini sesuai dengan pendapat Zareian et al. (2012) bahwa sebagian besar asam glutamat diproduksi oleh bakteri gram positif yang tidak membentuk spora, non-motil, dan membutuhkan biotin untuk tumbuh. Isolat IB.9 menunjukkan hasil negatif dalam pembentukan gas, hal ini sesuai dengan pendapat Purwohadisantoso et al. (2009) yang menyebutkan bahwa tidak terbentuknya gas sehingga menunjukkan bahwa isolat merupakan BAL homofermentatif.

Berdasarkan karakterisasi pada Tabel 2 dapat simpulkan bahwa isolat IB.9 merupakan Lactobacillus $s p$. Dengan ciriciri yaitu isolat bakteri bewarna putih susu dan memiliki sel berbentuk batang (baccil). Hal ini sesuai dengan pendapat Menurut Cullimore (2000) Lactobacillus memiliki sel yang berbentuk panjang, batang silinder (kadang-kadang melengkung) sedang yang lain pendek, sering berbentuk coryne atau batang bulat. Selnya juga sering membentuk rantai. Metabolismenya adalah metabolisme fermentatif dengan merubah setidaknya 50\% karbon menjadi asam laktat. Identifikasi BAL penghasil asam glutamat dilakukan pada isolat tertinggi dalam menghasilkan asam glutamat (Tabel 2).

\section{KESIMPULAN}

Berdasarkan hasil penelitian ini dapat disimpulkan bahwa terdapat 17 isolat BAL dan terdapat 16 isolat yang dapat menghasilkan asam glutamat. Isolat tertinggi menghasilkan asam glutamat terdapat pada isolat IB.9 dengan produksi $13.03 \mathrm{mg} / \mathrm{ml}$. Dua isolat isolat tertinggi IB.9 menghasilkan asam glutamat kemudian dikarakteristik sebagai Lactobacillus $s p$ dengan negatif katalase dan oksidase, dapat mensintesis glukosa, laktosa, dan mannitol.

\section{UCAPAN TERIMAKASIH}

Ucapan terimakasih saya sampaikan kepada Kementrian Riset Teknologi dan Pendidikan Tinggi Republik Indonesia yang telah mendukung penelitian ini dalam Program Pendidikan Magister Menuju Doktor (PMDSU).

\section{DAFTAR PUSTAKA}

Ajinomoto Animal Nutrition. 2007. Influence of Glutamic Acid on Broiler Carcass Quality.

Aman, Y. 2011. Ayam Kampung Unggul. Penerbit Penebar Swadaya, Jakarta.

Berres, J.S.L., Vieira, W.A. Dozier III, M.E.M. Cortês ,R. de Barros, E.T. Nogueira and M. Kutschenko. 2010. Broiler responses to reduced-protein diets supplemented with valine, isoleucine, glycine, and glutamic acid. Poultry Science Association, Inc. Vol. $19: 68-79$.

Collins, C.H. and D.M. Lyne. 1976. Microbiological methold. pp. 238-253.

Cullimore, R.D. 2000. Principal Atlas For Bacterial Identification. Lewis Publisher. United States of America. 
Direktorat Jenderal Peternakan. 2015. Statistik Peternakan. Direktorat Jenderal Peternakan, Jakarta.

Fujimura, S., H. Koga, H. Takeda, N. Tone, M. Kadowaki and T. Ishibashi. 1996. Role of taste-active components, glutamic acid, 5'-inosinic acid and potassium ion in taste of chicken meat extract. Animal Science and Technology 67, 423-429.

Fujimura, S., F. Sakai and M. Kadowaki. 2001. Effect of restricted feeding before marketing on taste active components of broiler chickens. Journal of Animal Science 72: 223-229.

Gordon, R.E., W.C. Haynes and C.H. Pang. 1973. Thr genus Bacillus. Wanghiton DC. US department of agriculture. Agricultural Handbook. Hal.42.

Imanari, M., Kadowaki and Fujimura. 2004. Regulation of taste-active components of meat bg diatary branchedchain amino acids. Proc. $50^{\text {th }}$ int/ cong. Meat Sci.Technol : 1276-1277.

Kasih, N.S. 2012. Pengaruh Lama Penyimpanan Daging Ayam Segar Dalam Refrigator Terhadap $\mathrm{pH}$, Susut Masak, dan Organoleptik. Skripsi. Fakultas Pertanian. Universitas Islam Kalimantan Muhammad Aryad Al Banjary. Banjarmasin.

Kato, H. and T. Nishimura. 1987. Taste components and condition of beef, pork and chicken. In: Kawamura Y, Kare RM (eds), Umami, A Basic Taste, pp. 289-306. Marcel Dekker, New York. Kong SE, Hall JC

Kiboem, L., J. Lee, Y.H. Kim, S.H. Moon and Y.H. Park. 2001. Unique properties of four Lactobacillus in amino acid production and symbiotic mixed culture for lactic acid biosynthesis. Gun. Microb. Vol 43 : 123-131.

Kondoh, T., H.N. Mallick and K. Torii. 2009. ctivation of the gut-brain axis by dietary glutamate and physiologic significance in energy homeostasis. Am. J. Clin. Nutr. Vol: 90, 832S-837S.
Lawal, A.K., B.A. Oso, A.I. Sanni and, O.O. Olatunji. 2011. L-Glutamic acid production by Bacillus spp. Isolated from vegetable proteins. African Journal of Biotechnology . 10: 53375345.

Lawrie, R. and D.H. Ledward. 2006. Lawrie's Meat Science, 7th edn. Woodhead, Cambridge. assessment of the isolates for industrial potential. Bioresour. Technol. 2007, 98, 1380-1385.

Ogbadu, L. J., Okagbue, R. N, and Ahmed, A. A. 1990. Glutamic acid production by Bacillus isolates from fermented vegetable proteins. J. Microbiol. 6: 377-382.

Pierre-Andre, G. and M. Yves. 2004. Amino Acids: Beyond the Building Blocks Poult. Sci 83:650-657.

Purwohadisantoso, K., E. Zubaidah and T. Saparianti. 2009. Isolation of lactic acid bacteria from cabbage and their potensial inhibition to pathogenic bacteria (Staphylococcus aureus, Listeria monocytogenes, Escherichia coli and Salmonella thypimurium). Jurnal Teknologi Pertanian 10(1): 1927.

Ray, B. 2001. Dasar-dasar Mikrobiologi Pangan. Diterjemahkan oleh Rindit Pambayun dan Rahmat Hari Purnomo. Jurusan Teknologi Pertanian. Fakultas Pertanian Universitas Sriwijaya.

Sano, C. 2009. History of glutamate production. Am. J. Clin. Nutr. 90, 728S-732S.

Sneath, P.H.A., Mair, M.E. Sharpe, and J.G. Holt. 1986. Bergey's Manual of Systematic Bacteriology; Williams and Wilkins ; Baltimore. MD. USA.

Spies, J. R. 1957. Colorimetric procedures for amino acids methods in Enzymology. 3: 468-471

Tarek, M. El-Nemr and H.E. Mostafa. 2010. Screening Of potensial infans Ilactobacili isolat for amino acids 
production.Alexandria. African Jurnal Of Microbiology research vol. 4 (4),pp. 226-232.

Winarno, F.G. 1990. Teknologi Fermentasi. Proyek Pengembangan Pusat Fasilitas bersama . Antar Universitas, PAU Pangan dan Gizi, UGM, Yogyakarta.

Winarno, F.G. 2004.Kimia Pangan dan Gizi. Gramedia Pustaka Utama. Jakarta.

Young, J.F., A.H. Karlsson and P. Henckel. 2004. Waterholding capacity in chicken breast muscle is enhanced by pyruvate and reduced by creatine supplements. Poultry Science 83: 400-405.

Young, V.R. and A.M. Ajami. 2000. Glutamate: an amino acid of particular distinction. Journal of Nutrition. Vol .130: 892S-900S.

Yusra, A. Fauza, Novelina,dan Periadnadi.
2014. Isolasi dan identifikasi mikroflora indigenous dalam budu. Agritech : 34

Zalan, Z., J. Hudacek, J. Stetina, and J. Chumchalova. 2010, Production of organic acids by Lactobacillus strains in three different media. Eur. Food Res. Technol. 230, 395-404.

Zhang, G.Q., Q.G. Ma and C. Ji. 2008. Effects of dietary inosinic acid on carcass characteristics, meat quality, and deposition of inosinic acid in broilers. Poult. Sci

Zareian, M., A. Ebrahimpour, F.A. Bakar, A.K.S. Mohamed, B. Forghani, M.S.B. Ab-Kadir and N. Saari. 2012. A glutamic acid-producing lactic acid bacteria isolated from Malaysian Fermented foods. International Journal of Molecular Sciences. 